\title{
MOOD STRUCTURE TYPE OF THE CLAUSE ANALYSIS IN ENGLISH TEXT BOOKS OF SMA: A DISCOURSE STUDY BASED ON SYSTEMIC FUNCTIONAL LINGUISTIC THEORY
}

\author{
Fatimah Kesuma Astuti *)
}

\begin{abstract}
This study aims at analyzing mood structure type of the clause on recount and procedure text in English textbooks of SMA where it was analyzed based on the mood structure types of the clause. It was designed as a descriptive qualitative study and discourse analysis. Data were collected through documentation method. The technique in collecting the data is by determining the source to be investigated, determining the supporting resources, and seeking the recount and procedure text on the English textbook. The Data were analyzed using Mood structure analysis suggested by M.A.K Haliday. In analyzing the data, the activities did by deep reading, identifying, classifying, analyzing, and calculating the percentages. Based on the results of the data analysis, the findings of this research can be stated as follows: (1) There are some types of mood structure in the English textbooks of SMA at the tenth grade students which published by Pusat Perbukuan Departemen Pendidikan Nasional especially on recount text, they are indicative: declarative mood $(99,41 \%)$, indicative: interrogative mood $(0,59 \%)$, and imperative mood (0\%). (2) The results of mood structure type on procedure text are indicative: declarative mood (25,62\%), indicative: interrogative mood $(0 \%)$, and imperative mood $(74,38 \%)$. (3) The results in the textbook which published by Yudhistira especially on recount text are indicative: declarative mood $(98,94 \%)$, indicative: interrogative mood $(1,06 \%)$, and imperative mood $(0 \%)$, and also on procedure text are indicative: declarative mood (25\%), indicative: interrogative mood (0\%), and imperative $\operatorname{mood}(75 \%)$.
\end{abstract}

Keywords: Discourse analysis, SFL, mood structure, recount text, procedure text.

\section{INTRODUCTION}

Language is communication through people that communicate or express their feelings and thought to others by the use of signs, gestures, sounds, or mark which having an understanding meaning. A successful communication in another language involves another paradigm. It means that when we are using another language, we are shifting into a different cultural frame. Since we are living in a nonEnglish speaking country, one way to learn about English cultural frames is by reading, writing, and discussing English text.

In linguistic, analysis is a qualitative method to do the study a language to examine the structure of language in depth. Analyzing a text based on Systemic Functional Linguistics (SFL) needs an understanding of the framework of SFL tradition. SFL believes that language is a set of semiotic or symbol in the context of situation and the context of culture, realizes a particular meaning or particular social goal 
(Santosa, 2006: 86). One of analysis could be used for analyzing mood structure type of the clause in the English textbooks of SMA. Mood structure defined as a grammar form expressing the interpersonal meaning of a clause, containing two elements: mood and residue (Santosa, 2006: 91). In analyzing a text, it needs some theories related to the study. They could be found in journals, textbook, internet, and the others. It is not easy to analyze the text, because it depends on the ability of someone in mastering the language learning. Furthermore, a text which is analyzed could be gotten from internet, textbook, newspaper, magazine, and the others which related to the study that will be analyzed.

Based on the descriptive above, this study was primarily intended to identify the mood structure types of the clause in the English textbook of SMA especially contained on recount and procedure text in the textbook itself. The textbooks used in this study were the tenth grade textbook of SMA by the title of Developing English Competencies for Senior High School (SMA/MA) which published by Pusat Perbukuan Departemen Pendidikan Nasional and also the textbook by the title of Linked to the World English for Senior High School which published by Yudhistira.

The result of this study is expected to be useful theoretical and practical significance in relation to English language education in Indonesia as well as to do the research in language teaching. Theoretically, the result of this study was expected to provide beneficial information about linguistic features in the recount and procedure text, to provide information about textual analysis, so that this study gained many insights into this relationship, which in turn contributed, even probably in small scale, to the theories of language education, teaching and learning English as a foreign language (Van Lier, 1989; Ellis, 1986). Practically, this study may provide information about the use of functional grammar as a tool for textual analysis in language studies.

\section{METHOD OF STUDY}

A descriptive-qualitative design and discourse analysis were used in this study. According to Clisset (as cited in Tavallaei \& Abu Thalib, 2010: 571), qualitative study is the research process which covers a wide range of approaches for the exploration of human experience, perceptions, motivations, behaviors, and it its concerned with the collection and analysis of words whether in the form of speech or writing.

The data of the research are the performances in the frame of Systemic Functional Linguistics such as complexity of the clause and text structure. This study also used descriptive approach because this study was done to relate the answer of the problem, 
to collect the data, analyze and also interpret the data.

This study was conducted by analyzing the mood structure type of the clause on recount and procedure text in the English textbooks of SMA. It was conducted for seeking the information to assist in decision making. By analyzing a clause from the words and structure of the clause in mood system, it enabled interpersonal meanings of a whole text to be interpreted semantically so that mood of text could be described.

The data was collected by using documentation method. It was done by seeking the data about things or variables in the form of notes, transcripts, books, newspaper, magazines, and the other which relate by the source of the study (Arikunto, 2010: 274). The data collected is qualitative data, where it means that data which is drawn with words and sentences, clustered follows its category to get conclusion.

The technique in collecting data in this analysis involved several activities as follow:

1. Determining the object to be analyzed.

In this study used the English textbooks of SMA at the tenth grade by the title of Developing English Competencies for Senior High School (SMA/MA) which published by Pusat Perbukuan Departemen Pendidikan Nasional and also by the title of Linked to the World English for Senior High School which published by Yudhistira as the object to be analyzed.

2. Determining the supporting references.

The supporting references were gotten from some sources, such as internet, books, journals and articles.

3. Seeking the recount and procedure text on the English textbooks.

This study focused on recount and procedure text found in English textbooks of SMA as the object to be analyzed.

Then, the technique in analyzing data in this analysis used some steps, it was described as follow:

1. Deep reading

The first step for analyzing the data is doing the activities by reading that is deep reading, where it was mean that the active process of thoughtful and deliberate reading carried out to enhance one's comprehension as enjoyment of a text. It was the kind of reading encouraged by common core standards, asked reader to "read like a detective" where they were looking closely for details.

2. Identifying

After reading was completely done, the next step is identifying. The writer determined amount of the clause in each sentence, then identifying the mood structure of the clause which contained in each text. The implication of identifying 
ideology in text is that as reading of texts, we need to develop skills to be able to make explicit the ideological positions encoded, perhaps in order to resist or challenge them (Sutopo, 2009: 17).

3. Classifying

In this step, the data which had been identified, then classifying based on the structure of mood. It was conducted in each clause of the text. Mood described as the overall structure of the clause, which consisted of subject and finite operator. Subject was realized by a nominal group; while Finite defined as terms of function in the clause to make the proposition definite, to anchor the proposition in a way that we can argue about it. Meanwhile, the part of the clause which was the rest of sentence was called Residue. The Residue component could contain a number of functional elements: a Predicator, one or more Complements, and any number of different types of Adjuncts. The mood of the clause could be realized in the classifying of clause system, they were indicative and imperative. Meanwhile indicative was further classified into two, they were declarative and interrogative (Santosa, 2006:91).

4. Analyzing

In this step, the data which had been collected and classified was analyzed. The sentence in each clause was analyzed by determining the mood (consists of Subject and Finite in each sentence) and residue which consisted of Predicator, Complement, and Adjunct). After the text on all the recount and procedure text of English textbook had been analyzed, then determined the type of mood structure which contained on recount and procedure text in the English textbook of SMA at the tenth grade by the title of Developing English Competencies for Senior High School (SMA/MA) which published by Pusat Perbukuan Departemen Pendidikan Nasional in the year of 2008 and also by the title of Linked to the World English for Senior High School which published by Yudhistira in the year of 2007. The text was analyzed as follow:

Table 1

An analyze of the clause

a. Indicative: declarative mood

\begin{tabular}{|c|c|c|c|c|}
\hline \multicolumn{5}{|c|}{ CLAUSE SENTENCE } \\
\hline S & F & P & C & A \\
\hline & & \multicolumn{3}{|c|}{ Residue } \\
\hline
\end{tabular}


b. Indicative: Interrogative mood

c. Imperative mood

\begin{tabular}{|c|c|c|c|c|}
\hline \multicolumn{5}{|c|}{ CLAUSE SENTENCE } \\
\hline F & S & P & C & A \\
\hline \multicolumn{7}{|c|}{ MOOD TYPE } \\
\hline \multicolumn{4}{|c|}{ Residue } \\
\hline
\end{tabular}

\begin{tabular}{|l|c|c|c|c|}
\hline \multicolumn{5}{|c|}{ CLAUSE SENTENCE } \\
\hline HS & F & P & C & A \\
\hline \multicolumn{4}{|c|}{ Mood } & \multicolumn{3}{|c|}{ Residue } \\
\hline \multicolumn{5}{|c|}{ MOOD TYPE } \\
\hline
\end{tabular}

Noted:

Clause Sentence: The Clause in the sentence

$\mathrm{S}$

: Subject (Nominal Group)

HS : Hidden Subject

F : Finite (Verbal Group)

$\mathrm{P} \quad$ : Predicator (the lexical or content part of the verbal group)

C : Complement (an object that can be a subject in a clause, if it is changed to be passive)

A : Adjunct (additional information that is adverbial or prepositional)

Then to analyze the type of their occurrences, used the rubrics below as follow:

Table 2

Rubric for Checking the Occurrences of Mood Structure Type of the Clause on Recount Text in the Textbook of SMA at the Tenth Grade Students Published by Pusat Perbukuan Departemen Pendidikan Nasional

\begin{tabular}{|c|c|c|c|c|c|}
\hline \multirow{2}{*}{ Criteria } & \multicolumn{5}{|c|}{ Recount Text } \\
\cline { 2 - 6 } & \multirow{2}{*}{ Text I } & Text II & Text III & Text IV & Text V \\
\hline $\mathrm{A}$ & & & & & \\
\hline $\mathrm{B}$ & & & & & \\
\hline
\end{tabular}

Noted:

Text I : Meeting a Star

A : Indicative: declarative mood 
Text II : My Day

Text III: The text on activity 7 (untitled)

Text IV: R.A. Kartini

Text V : Blind Date
B : Indicative: interrogative mood

C : Imperative mood

Table 3

Rubric for Checking the Occurrences of Mood Structure Type of the Clause on Procedure Text in the Textbook of SMA at the Tenth Grade Students Published by Pusat Perbukuan Departemen Pendidikan Nasional

\begin{tabular}{|c|c|c|c|c|c|c|c|c|c|c|}
\hline \multirow{2}{*}{ Text } & \multicolumn{7}{|c|}{ Procedure Text } \\
\cline { 2 - 11 } Criteria & I & II & III & IV & V & VI & VII & VIII & IX & X \\
\hline A & & & & & & & & & & \\
\hline B & & & & & & & & & & \\
\hline C & & & & & & & & & & \\
\hline
\end{tabular}

Noted:

Text I : How to Cook Spiced Chicken

Text II : How to Barbecue Lamb

Text III: Tomato Soup

Text IV: Egg and Lemon Soup

Text V : Ways to Show the Problems with Gadget

Text VI: How to Operate a Fan

Text VII: Bregedel Tempe (Tempe Fritters)

Text VIII: How to Find Unusual Gifts

Text IX: How to Prepare Fried Rice

Text X: Making an Omelette
A: Indicative: declarative mood
B: Indicative: interrogative mood
C: Imperative mood

Table 4

Rubric for Checking the Occurrences of Mood Structure Type of the Clause on Recount Text in the Textbook of SMA at the Tenth Grade Students Published by Yudhistira

\begin{tabular}{|c|c|c|c|}
\hline \multirow{2}{*}{ Criteria } & \multicolumn{3}{|c|}{ Rext } \\
\cline { 2 - 4 } & Text I & Text II & Text III \\
\hline $\mathrm{A}$ & & & \\
\hline $\mathrm{B}$ & & & \\
\hline $\mathrm{C}$ & & & \\
\hline
\end{tabular}


Noted:

Text I : My Friend Sarah

Text II : The Most Important Day in My Live

Text III: An Unforgettable Experience
A: Indicative: declarative mood
B: Indicative: interrogative mood
C: Imperative mood

Table 5

Rubric for Checking the Occurrences of Mood Structure Type of the Clause on Procedure Text in the Textbook of SMA at the Tenth Grade Students Published by Yudhistira

\begin{tabular}{|c|c|c|c|}
\hline \multirow{2}{*}{ Criteria } & \multicolumn{3}{|c|}{ Procedure Text } \\
\cline { 2 - 4 } & \multirow{2}{*}{ Text I } & Text II & Text III \\
\hline $\mathrm{A}$ & & & \\
\hline $\mathrm{B}$ & & & \\
\hline $\mathrm{C}$ & & & \\
\hline
\end{tabular}

Noted:

Text I : Making Passport

Text II : Stuffed Baked Potatoes

Text III: How to Develop the Tourism in Indonesia
A: Indicative: declarative mood

B: Indicative: interrogative mood

C: Imperative mood
5. Calculating the percentage

In this step, the data which had been analyzed was changed into percentages, it conducted to get the percentage of mood structure type of the clause.

In calculating the data, the writer used the formula:

$$
\mathrm{P}=\frac{\mathrm{F}}{\mathrm{N}} \times 100 \%
$$

Noted:

$\mathrm{P}=$ percentage

$\mathrm{F}=$ frequency (the total of all the texts in one of the type)

$\mathrm{N}=$ total number in mood structure type of the clause / the total of all the texts in all of types (Sudijono, 2005: 43)

Therefore, to calculate the frequency of their occurrences used the rubrics as the following:

Table 6

Rubric for Calculating the Percentages of Mood Structure Type of the Clause on Recount Text in the Textbook of SMA at the Tenth Grade Students Published by Pusat Perbukuan Departemen Pendidikan Nasional 


\begin{tabular}{|c|c|c|c|c|c|c|c|}
\hline Text & \multicolumn{5}{|c|}{ Recount Text } & \multirow{2}{*}{$\begin{array}{l}\text { Frequency } \\
\text { (F) }\end{array}$} & \multirow{2}{*}{$\begin{array}{c}\text { Percentage }(P) \\
(P=F / N \times 100 \%)\end{array}$} \\
\hline Criteria & I & II & III & IV & $\mathbf{V}$ & & \\
\hline A & & & & & & & \\
\hline $\mathrm{B}$ & & & & & & & \\
\hline $\mathrm{C}$ & & & & & & & \\
\hline $\begin{array}{c}\text { Total Number } \\
(\mathbf{N})\end{array}$ & & & & & & & \\
\hline
\end{tabular}

Noted:

Text I : Meeting a Star

Text II : My Day

Text III: The text on activity 7 (untitled)

Text IV: R.A. Kartini

Text V : Blind Date
A: Indicative: declarative mood

B: Indicative: interrogative mood

C: Imperative mood

$\mathrm{P}=$ Percentage

$\mathrm{F}=$ Frequency (the total of all the texts in one of the type)

$\mathrm{N}=$ Total number in mood structure type of the clause / the total of all the texts in all of types (Sudijono, 2005: 43)

Table 7

Rubric for Calculating the Percentages of Mood Structure Type of the Clause on Procedure Text in the Textbook of SMA at the Tenth Grade Students Published by Pusat Perbukuan Departemen Pendidikan Nasional

\begin{tabular}{|c|c|c|c|c|c|c|c|c|c|c|c|c|}
\hline \multirow{9}{*}{ Text } & \multicolumn{9}{|c|}{ Procedure Text } & \multicolumn{1}{c|}{$\begin{array}{c}\text { Frequency } \\
\text { (F) }\end{array}$} & $\begin{array}{c}\text { Percentage (P) } \\
\text { (P=F/N x 100\%) }\end{array}$ \\
\cline { 2 - 10 } Criteria & I & II & III & IV & V & VI & VII & VIII & IX & X & & \\
\hline A & & & & & & & & & & & & \\
\hline B & & & & & & & & & & & & \\
\hline C & & & & & & & & & & & & \\
\hline $\begin{array}{c}\text { Total } \\
\text { Number } \\
\text { (N) }\end{array}$ & & & & & & & & & & & & \\
\hline
\end{tabular}

Noted 1:

Text I : How to Cook Spiced Chicken

Text II : How to Barbecue Lamb

Text III: Tomato Soup

Text IV: Egg and Lemon Soup

Text V : Ways to Show the Problems with Gadget

Text VI: How to Operate a Fan

Text VII: Bregedel Tempe (Tempe Fritters)

Text VIII: How to Find Unusual Gifts
Text IX: How to Prepare Fried Rice

Text X : Making an Omelette

A: Indicative: declarative mood

B: Indicative: interrogative mood

C: Imperative mood 
Noted 2:

$\mathrm{P}=$ Percentage

$\mathrm{F}=$ Frequency (the total of all the texts in one of the type)

$\mathrm{N}=$ Total number in mood structure type of the clause / the total of all the texts in all of types (Sudijono, 2005: 43)

Table 8

Rubric for Calculating the Percentages of Mood Structure Type of the Clause on Recount Text in the Textbook of SMA at the Tenth Grade Students Published by Yudhistira

\begin{tabular}{|c|c|c|c|c|c|}
\hline \multirow{2}{*}{ Criteria } & \multicolumn{3}{|c|}{ Recount Text } & \multirow{2}{*}{$\begin{array}{c}\text { Frequency } \\
\text { (F) }\end{array}$} & $\begin{array}{c}\text { Percentage (P) } \\
\text { (P=F/N x 100\%) }\end{array}$ \\
\cline { 2 - 6 } & I & II & III & & \\
\hline A & & & & & \\
\hline C & & & & & \\
\hline $\begin{array}{c}\text { Total } \\
\text { Number (N) }\end{array}$ & & & & & \\
\hline
\end{tabular}

Noted:

Text I : My Friend Sarah

Text II : The Most Important Day in My Live

Text III: An Unforgettable Experience
A: Indicative: declarative mood

B: Indicative: interrogative mood

C: Imperative mood

$\mathrm{P}=$ Percentage

$\mathrm{F}=$ Frequency (the total of all the texts in one of the type)

$\mathrm{N}=$ Total number in mood structure type of the clause / the total of all the texts in all of types (Sudijono, 2005: 43)

Table 9

Rubric for Calculating the Percentages of Mood Structure Type of the Clause on Procedure Text in the Textbook of SMA at the Tenth Grade Students Published by Yudhistira

\begin{tabular}{|c|c|c|c|c|c|}
\hline \multirow{2}{*}{ Criteria } & \multicolumn{3}{|c|}{ Procedure Text } & \multirow{2}{*}{$\begin{array}{c}\text { Frequency } \\
\text { (F) }\end{array}$} & $\begin{array}{c}\text { Percentage (P) } \\
\text { (P=F/N x 100\%) }\end{array}$ \\
\cline { 2 - 4 } & I & II & III & & \\
\hline A & & & & & \\
\hline B & & & & & \\
\hline C & & & & & \\
\hline $\begin{array}{c}\text { Total } \\
\text { Number (N) }\end{array}$ & & & & & \\
\hline
\end{tabular}


Noted:

Text I : Making Passport

Text II : Stuffed Baked Potatoes

Text III: How to Develop the Tourism
A: Indicative: declarative mood

B: Indicative: interrogative mood

C: Imperative mood in Indonesia

$\mathrm{P}=$ Percentage

$\mathrm{F}=$ Frequency (the total of all the texts in one of the type)

$\mathrm{N}=$ Total number in mood structure type of the clause / the total of all the texts in all of types (Sudijono, 2005: 43)

\section{FINDINGS AND}

\section{INTERPRETATIONS}

Based on the data gained in the research, there were five recount and ten procedure texts found in the English textbook of SMA at the tenth grade by the title of Developing English Competencies for Senior High School (SMA/MA) published by Pusat Perbukuan Departemen Pendidikan Nasional. The title of the texts can be seen in the table as follow:

Table 10

\section{Recount and Procedure Text in the English Textbook of SMA at the Tent Grade Students Published by Pusat Perbukuan Departemen Pendidikan Nasional}

\begin{tabular}{|l|l|}
\hline \multicolumn{1}{|c|}{ Recount Text } & \multicolumn{1}{c|}{ Procedure Text } \\
\hline (1) Meeting a Star, page 13 & (1) How to Cook Spiced Chicken, page 63 \\
\hline (2) My day, page 14 & (2) How to Barbecue Lamb, page 63 \\
\hline (3) The text on activity 7 (untitled), page 16 & (3) Tomato Soup, page 64 \\
\hline (4) R.A. Kartini, page 20 & (4) Egg and Lemon Soup, page 64 \\
\hline (5) Blind Date, page 20-21 & (5) Ways to Show the Problems with Gadget, page 65 \\
\hline \multirow{5}{*}{} & (6) How to Operate a Fan, page 66 \\
\cline { 2 - 2 } & (7) Bregedel Tempe (Tempe Fritters), page 66 \\
\cline { 2 - 2 } & (8) How to Find Unusual Gifts, page 68 \\
\cline { 2 - 2 } & (9) How to Prepare Fried Rice \\
\cline { 2 - 2 } & (10) Making an Omellete, page 76 \\
\hline
\end{tabular}

Besides of that, there were also found three recount and procedure texts in the English textbook of SMA at the tenth grade by the title of The World English for Senior
High School published by Yudhistira. The title of the texts can be seen in the table as follow: 
Table 11

Recount and Procedure Text in the English textbook of SMA at the Tenth Grade Students published by Yudhistira

\begin{tabular}{|l|l|}
\hline \multicolumn{1}{|c|}{ Recount Text } & \multicolumn{1}{c|}{ Procedure Text } \\
\hline (1) My Friend Sarah, page 6 & (1) Making Passport, page 43 \\
\hline (2) The Most Important Day in My Live, page 8-9 & (2) Stuffed Baked Potatoes, page 46 \\
\hline (3) An Unforgettable Experience, page 9-10 & $\begin{array}{l}\text { (3) How to Develop the Tourism in Indonesia, } \\
\text { page 47 }\end{array}$ \\
\hline
\end{tabular}

Whereas the result of the data that had been analyzed were shown in the table as follow:

Table 12

Types of Mood Structure of the Clause in the English Textbooks

\begin{tabular}{|c|l|c|c|c|c|}
\hline \multirow{2}{*}{ No. } & \multicolumn{2}{|c|}{ Mood structure types } & \multicolumn{2}{|c|}{ Text types } & \multicolumn{2}{c|}{ Text types } \\
\cline { 3 - 6 } & & Recount & Procedure & Recount & Procedure \\
\cline { 3 - 6 } & & $\mathbf{9 9 , 4 1 \%}$ & $\mathbf{2 5 , 6 2 \%}$ & $\mathbf{9 8 , 9 4 \%}$ & $\mathbf{2 5 \%}$ \\
\hline 2. & Indicative: declarative mood & & & & $\mathbf{0 \%}$ \\
\hline 3. & Indicative: interrogative mood & $\mathbf{0 , 5 9 \%}$ & $\mathbf{0 \%} \%$ & $\mathbf{1 5 \%}$ \\
\hline
\end{tabular}

Noted:

Text types A : The types of text in the English textbook of SMA published by Pusat Perbukuan Departemen Pendidikan Nasional

Text types B : The types of text in the English textbook of SMA published by Yudhistira

From the table above described that statements which expressed by a speaker's there were some types of mood which was utterance was offered as an unqualified found in each textbook. The first one in the statement of fact, people always used declare textbook of Pusat Perbukuan Departemen in their daily life to conveyed the messages, Pendidikan Nasional, especially on recount desires, meanings, needs, thoughts or text, the types of mood were dominant in opinions. As well as in the textbook of indicative: declarative mood $(99,41 \%)$. It was Yudhistira, type of mood found in recount caused in the analysis of the clause before. It text also more dominant in indicative: had been found the mood structure which was declarative $\operatorname{mood}(98,94 \%)$. Type of consisted of pattern $\mathrm{S}+\mathrm{F}+$ Residue, indicative: interrogative mood in recount text furthermore in recount text consisted of between the textbook of Pusat Perbukuan 
Departemen Pendidikan Nasional and textbooks was not occurred, because in Yudhistira was very minimal to be occurred, recount text were not occur the sentences because in recount text almost did not appear which was formed of interrogative.

the sentences which were formed of interrogative. As well as in the type of IV. CONCLUSIONS imperative mood on recount text of both From the findings and interpretations textbooks was not occurred. The findings elaborated previously, it can be concluded above tell us that there was no difference that there are two types of mood structure of mood types occurrences in recount text the clause they are indicative and imperative between the textbook of Pusat Departemen mood. Meanwhile indicative is further Pendidikan Nasional with the textbook which classified into two, they are declarative and published by Yudhistira. interrogative. The writer found the

Meanwhile the second one in the percentages of mood structure types of the textbook of Pusat Perbukuan Departemen clause in the English textbook of SMA at the Pendidikan Nasional which was in the form tenth grade students which published by Pusat of procedure text, the types of mood are Perbukuan Departemen Pendidikan Nasional, dominant in imperative mood $(74,38 \%)$, especially on recount text are indicative: because in the analysis of the clause before, It declarative $\operatorname{mood}(99,41 \%)$, indicative: had been found the mood structure which is interrogative mood $(0,59 \%)$, and imperative consisted of pattern HS $+F+$ Residue, mood $(0 \%)$. Whereas, the results of mood furthermore in procedure text consisted of structure type in procedure text are indicative: instructions to do or make something, so the declarative $\operatorname{mood}(25,62 \%)$, indicative: text was almost all in the form of imperative interrogative mood $(0 \%)$, and imperative mood. As well as in the textbook of $\operatorname{mood}(74,38 \%)$.

Yudhistira, type of mood found in procedure Besides of that, it also found the text was more dominant in imperative mood percentages of mood structure type of the (75\%). Whereas type of indicative: clause in the English textbook of SMA at the declarative mood in procedure text between tenth grade students which published by the textbook of Pusat Perbukuan Departemen Yudhistira, especially on recount text are Pendidikan Nasional and Yudhistira was very indicative: declarative mood (98,94\%), minimal to be occurred, because it only as the indicative: interrogative mood $(1,06 \%)$, and explanation of the text which was used in the imperative mood $(0 \%)$. Whereas, the results procedural. As well as in the type of of mood structure type in procedure text are interrogative mood on procedure text of both indicative: declarative mood (25\%), 
indicative: interrogative mood $(0 \%)$, and imperative mood $(75 \%)$.

In summary, as a general understanding, the most texts appeared in the English textbook of SMA at the tenth grade students published by Pusat Perbukuan Departemen Nasional and also Yudhistira especially on recount text are the most dominant in indicative: declarative mood types, whereas on procedure text are the most dominant in imperative mood types. They were occurred caused of the types of mood are influenced by the structure of mood and the types of text that will be analyzed.

\section{REFERENCES}

Arikunto, S. 2010. Prosedur Penelitian: Suatu Pendekatan Praktik. Jakarta: PT Rineka Cipta.

Clissett, P. 2008. Evaluating Qualitative Research. Journal of Orthopedic Nursing, 12, 99-105. In Tavallaei, M., \& Abu Thalib, M. (Ed.). (2010). A
General on Role of Theory in Qualitative Research. The Journal of International Social Research, 3(11), 570-577.

Ellis, R. 1986. Understanding Second Language Acquisition. New York: Oxford University Press.

Halliday, M.A.K., \& Matthiessen, C. 2004. Systemic Functional Grammar: A First Step into the Theory. London: Printer.

Lier, L. V. 1988. Teacher and Learners: Investigating the Language Classroom. London and New York: Longman.

Santosa, R. 2006. Register in Advertisement: A case Study of a Car Advertisement (Systemic Functional Linguistic Approach), 10(2): 86-91.

Sudijono, A. 2005. Pengantar Statistik Pendidikan. Jakarta: PT. Raja Grafindo Persada.

Sutopo, D. 2009. The Language of Political Campaign. Language Circle Journal of Language and Literature, 3(2), 1322. 